\title{
CORRECTION
}

\section{Heritability of cervical spinal cord structure}

Neurol Genet 2020;6:e419. doi:10.1212/NXG.0000000000000419

In the article "Heritability of cervical spinal cord structure" by Dahlberg et al., first published online February 26, 2020, figures 2 and 3 should have been switched to match their correct legends. The editorial office regrets the error.

\section{Reference}

1. Dahlberg LS, Viessmann O, Linnman C. Heritability of cervical spinal cord structure. Neurol Genet 2020;6:e401. doi: 10.1212/ NXG.0000000000000401. 


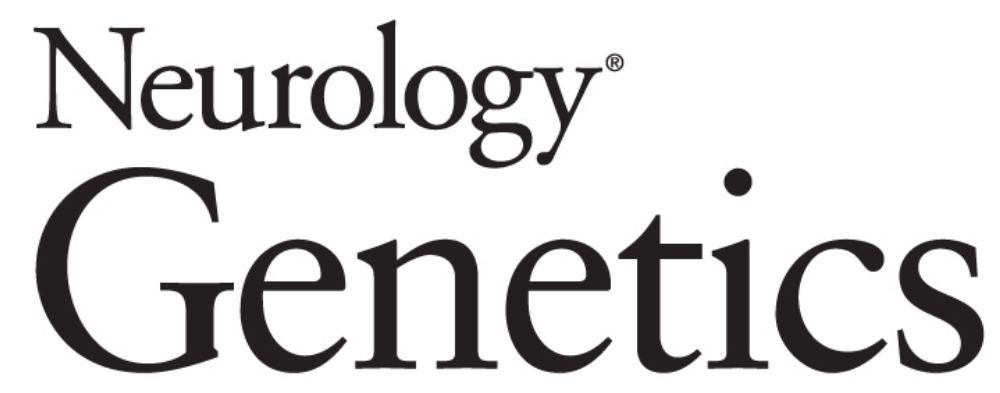

\section{Heritability of cervical spinal cord structure \\ Neurol Genet 2020;6; \\ DOI 10.1212/NXG.0000000000000419}

This information is current as of March 18, 2020

\section{Updated Information \&} Services

References

Permissions \& Licensing

Reprints including high resolution figures, can be found at: http://ng.neurology.org/content/6/2/e419.full.html

This article cites 1 articles, 1 of which you can access for free at: http://ng.neurology.org/content/6/2/e419.full.html\#\#ref-list-1

Information about reproducing this article in parts (figures,tables) or in its entirety can be found online at:

http://ng.neurology.org/misc/about.xhtml\#permissions

Information about ordering reprints can be found online: http://ng.neurology.org/misc/addir.xhtml\#reprintsus

Neurol Genet is an official journal of the American Academy of Neurology. Published since April 2015, it is an open-access, online-only, continuous publication journal. Copyright ( 2020 American Academy of Neurology. All rights reserved. Online ISSN: 2376-7839.

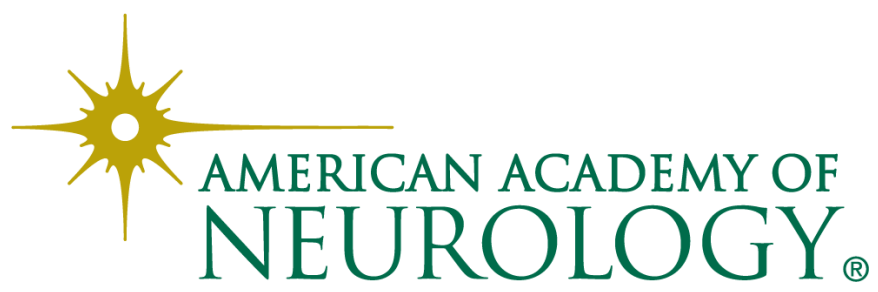

